\title{
In Search of a Working Strategy: The AHA... Moment in the Teaching of Science Subjects at Two South African High Schools
}

\author{
Kgomotsego B. Samuel ${ }^{1^{*}}$, Washington T. Dudu ${ }^{1}$ \\ ${ }^{1}$ School for Mathematics, Science and Technology, North-West University, SOUTH AFRICA
}

Received 24 January 2018 • Revised 5 May 2018 • Accepted 9 May 2018

\begin{abstract}
The purpose of this study is to interrogate a 'working' strategy established to improve and sustain learner performance by two Life Sciences and two Physical Sciences teachers of two best-performing high schools in the North West province of South Africa. The schools in this study have had a pass rate of over $90 \%$ for seven consecutive years in Physical and Life Sciences. Ausubel's (1963) constructs of Meaningful Reception Learning theory provided the conceptual framework for this study. The study was purely qualitative, employing an exploratory case-study approach. Purposive sampling was adopted to identify participants and research sites for the study. Data was generated through interviews, classroom observations and document analysis. The data were thematically analysed using open coding, axial coding and selective coding. Results of the study demonstrate that the aha! moment originated from the use of role-playing as a teaching strategy. Recommendations for policy and further research are suggested.
\end{abstract}

Keywords: aha! moment, case study research, learner performance, role-playing, meaningful reception learning theory

\section{INTRODUCTION}

Physical Sciences as a school subject in South Africa is generally characterised by poor performance amongst high school learners (Mavhungu, 2016). Outdated instructional teaching practices and lack of basic subject content knowledge amongst teachers have resulted in poor teaching standards in the subject and the overall South African education system (Makgato \& Mji, 2006). However, this is not the case in every public school. Mavhungu (2004) showed that the failure rate in Physical Sciences in most South African schools varies from region to region. According to BusinessTech (2018), education quality assurer uMalusi recently expressed delight that South Africa's science marks are improving; however, the actual numbers show that things are getting worse. Furthermore BusinessTech notes that the numbers are even more telling when looking at the passes in the ranges that give access to degrees that carry a high demand in the South African work space. Thus, the current trends are still prevalent in South Africa. The same can be said about Life Sciences. There has been a consistently poor record of performance in Life Sciences as a school subject in the past (Ferreira, 2011) with only some miniscule improvement reported. Similar trends still exist as noted by BusinessTech (2018) as Life Sciences is a science subject. Physical Sciences and Life Sciences are perceived to be difficult by South African learners as indicated by low performance (BusinessTech, 2018; Diagnostic report, 2017). The impediments to academic success and reasons for the poor performance are complex and only vaguely understood.

According to Kriek and Grayson (2009), some of the reasons include poverty, lack of resources, entrenched poor learning cultures, poor infrastructure in the schools, weak subject mastery amongst teachers, as well as insensitive regional distribution of Mathematics and Science teachers. Ramnarain and Fortus (2013) indirectly blamed teachers who lack specialist content knowledge and are incapable of implementing successful teaching strategies in their classrooms. Lee and Luft (2008) suggested that such teachers tend to rely heavily on textbooks, albeit without the necessary pedagogic strategies to stimulate receptive mastery of the concepts. With research suggesting that certain teaching practices seem to be more effective than others for particular learning domains, educational levels and

(C) 2018 by the authors; licensee Modestum Ltd., UK. This article is an open access article distributed under the terms and conditions of the Creative Commons Attribution License (http://creativecommons.org/licenses/by/4.0/). $\square$ Kgomotsego.Samuel@nwu.ac.za (*Correspondence) $\square$ Washington.Dudu@nwu.ac.za 


\section{Contribution of this paper to the literature}

- Role-playing provided the aha! moment as a 'working' teaching and learning strategy in two subjects perceived difficult by Grade 12 learners where performance is below the national average in a majority of schools in the North West province.

- The use of role-playing not only showed deviation from routine and superficial approaches which explain why South African learners are not performing well in Physical and Life Sciences as compared to international benchmarks. It also prepared the learners for examinations and fostered growth of scientific conceptual knowledge.

- Role-playing increased learner participation and encouraged them to use their background knowledge to acquire new information.

specific learner populations (Seidel \& Shavelson, 2007), a closer look at the aha! moment of Physical and Life Sciences teachers seems to be warranted. In most cases teachers clarify aims of their lessons, present the lessons and need to relate lesson content to their learners' prior knowledge. Teaching entails making the organisation of the new materials explicit, making logical order of the learning materials explicit. In all this, teachers should use examples and engage learners in meaningful learning activities to promote active reception learning. These are day-to-day duties of teachers. However, the aha! moment is when teachers are made aware of useful practices which they might not be practicing. According to Winfrey (2006):

What's really outstanding about those moments is usually when you hear something like that, it's it's - it's reminding you of what you already know. That's what the aha is, cause it feels like, 'I knew this; I just didn't know the words to put it,' you know? That's what's fabulous about it.

In the same vein, the assertion by Winfrey (2006) relates to how the aha moment is operationalised in this paper. This paper reports on the aha! moment (a point in time when the teachers had sudden insight into a 'working' teaching and learning strategy, to improve and sustain learner performance in the two subjects that are perceived to be difficult by learners and where performance is below the national average in a majority of schools in the North West province. The two schools (study sites) are labelled best-performing because they are amongst the schools which obtain between $90 \%$ and $100 \%$, despite not having enough resources just like the majority of South African schools. In the South African context, schools that perform at the 80-100\% range per subject and the overall school's achievement are labelled best-performing.

\section{Background to the Study}

In order to fully understand the background in which this study was undertaken, it is necessary to describe the context in which this research took place. Grade 12 examinations are set by the Department of Basic Education in South Africa. The term 'Department' is preferred and used in South Africa as opposed to 'Ministry'. Examinations are set according to the criteria outlined in the official curriculum statements. The Grade 12 examination are set by a group of selected subject specialists, some of whom are school-based teachers who have produced good results $(80-100 \%)$ pass rate. The other examiners are the subject advisors (in South Africa, these refer to senior subjectspecific education specialists). They are also known as office-based teachers who monitor curriculum implementation (Department of Basic Education, 2011a). These examinations are moderated by education officials responsible for curriculum monitoring, also known as provincial and national curriculum coordinators.

Each subject has its assessment requirements. In South Africa, Physical Sciences consists of two subjects which are Physics and Chemistry. In other African countries such as Zimbabwe and Malawi and European countries such as the United Kingdom, these two subjects are taught separately. The Physical Sciences examination consists of two sessions. Session 1 is Physics and session 2 is Chemistry. Each session's total is 150 marks as shown on Table 1. Each session has its specification of content, marks, duration and cognitive weighting. Duration for each session is three hours. As shown on Table 1, there are four content areas for session 1, whereas there are three content areas for session 2. Mark allocation for each content area is different, as shown on Table 1, with weightings of questions across cognitive levels (recall, comprehension, applying and analysing and synthesis). The distribution of marks for specific main knowledge areas is outlined in the 'pacesetters document' (guideline for the teachers to pace the progress of topics per term as per policy requirement). Syllabus coverage in the examinations is determined by the weighting of topics. 
Table 1. Physical Sciences

\begin{tabular}{|c|c|c|c|c|c|c|c|}
\hline \multicolumn{8}{|c|}{ Physics (Session 1): Physics Focus } \\
\hline \multirow{2}{*}{ Content } & \multirow{2}{*}{ Marks } & \multirow{2}{*}{ Total } & \multirow{2}{*}{ Duration } & \multicolumn{4}{|c|}{ Weighting of questions across cognitive levels in percentages (\%) } \\
\hline & & & & 1 & 2 & 3 & 4 \\
\hline Mechanics & 63 & \multirow{4}{*}{$\begin{array}{c}150 \\
\text { marks }\end{array}$} & \multirow{4}{*}{3 hours } & \multirow{4}{*}{15} & \multirow{4}{*}{35} & \multirow{4}{*}{40} & \multirow{4}{*}{10} \\
\hline Waves, sound and light & 17 & & & & & & \\
\hline Electricity and Magnetism & 55 & & & & & & \\
\hline Matter and Materials & 15 & & & & & & \\
\hline \multicolumn{8}{|c|}{ Chemistry (Session 2): Chemistry Focus } \\
\hline \multirow{2}{*}{ Content } & \multirow{2}{*}{ Marks } & \multirow{2}{*}{ Total } & \multirow{2}{*}{ Duration } & \multicolumn{4}{|c|}{ Weighting of questions across cognitive levels in percentages (\%) } \\
\hline & & & & 1 & 2 & 3 & 4 \\
\hline Chemical Change & 84 & \multirow{3}{*}{$\begin{array}{c}150 \\
\text { marks }\end{array}$} & \multirow{3}{*}{3 hours } & \multirow{3}{*}{15} & \multirow{3}{*}{40} & \multirow{3}{*}{35} & \multirow{3}{*}{10} \\
\hline Chemical Systems & 18 & & & & & & \\
\hline Matter and Materials & 48 & & & & & & \\
\hline
\end{tabular}

Table 2. Life Sciences Session 1

\begin{tabular}{|c|c|c|c|c|c|c|c|}
\hline \multirow{2}{*}{ Content } & \multirow{2}{*}{ Marks } & \multirow{2}{*}{ Total } & \multirow{2}{*}{ Duration } & \multicolumn{4}{|c|}{ Weighting of questions across cognitive levels in percentage (\%) } \\
\hline & & & & 1 & 2 & 3 & 4 \\
\hline Meiosis & 11 & \multirow{8}{*}{150} & \multirow{8}{*}{$\begin{array}{l}21 / 2 \\
\text { hours }\end{array}$} & \multirow{8}{*}{40} & \multirow{8}{*}{25} & \multirow{8}{*}{20} & \multirow{8}{*}{15} \\
\hline $\begin{array}{l}\text { Reproduction in } \\
\text { Vertebrates } \\
\end{array}$ & 6 & & & & & & \\
\hline Human Reproduction & 31 & & & & & & \\
\hline $\begin{array}{l}\text { Responding to be } \\
\text { environment (humans) }\end{array}$ & 40 & & & & & & \\
\hline Human endocrine system & 15 & & & & & & \\
\hline Homeostasis in humans & 11 & & & & & & \\
\hline $\begin{array}{l}\text { Responding to the } \\
\text { Environment (plants) }\end{array}$ & 11 & & & & & & \\
\hline Human impact (Grade 11) & 25 & & & & & & \\
\hline \multicolumn{8}{|c|}{ Life Sciences Session 2} \\
\hline DNA: Code of Life & 27 & \multirow{5}{*}{150} & \multirow{5}{*}{$\begin{array}{c}21 / 2 \\
\text { hours }\end{array}$} & \multirow{5}{*}{40} & \multirow{5}{*}{25} & \multirow{5}{*}{20} & \multirow{5}{*}{15} \\
\hline Meiosis & 12 & & & & & & \\
\hline Genetics and Inheritance & 45 & & & & & & \\
\hline $\begin{array}{l}\text { Evolution through Natural } \\
\text { Selection }\end{array}$ & 23 & & & & & & \\
\hline Human evolution & 43 & & & & & & \\
\hline
\end{tabular}

Life Sciences is known as Biology in the countries as stated above, excluding South Africa. In South Africa, the Life Sciences examination is written in two separate sessions, i.e. session 1 and 2 each carrying a total of 150 marks. As shown on Table 2, session 1 covers eight content areas and session 2 covers five content areas. Each session's total is 150 marks as shown on Table 2. Each session has its specification of content, marks, duration and cognitive weighting. Mark allocation for each content area is different. Duration for each session is two and a half hours. Both sessions have the same cognitive weightings for topics across cognitive levels (recall, comprehension, applying and analysing and synthesis). The distribution of marks for specific main knowledge areas is outlined in the 'pacesetters document' (guideline for the teachers to pace the progress of topics per term as per policy requirement). Syllabus coverage in the examinations is determined by the weighting of topics. The duration of each session is two and a half hours (Department of Basic Education, 2011b).

The examination marking is centralised. Each province arranges a number of venues at which the scripts are marked. The provinces collect papers from schools under tight security; these are sent to the provincial examination office for administration purposes and ultimately to the marking centres. The scripts are marked by selected teachers who have been teaching the subject for three years or more and have produced $80-100 \%$ pass rate in three consecutive years counting from the current year of teaching (Department of Basic Education, 2011b). The marked scripts are moderated twice, first by the senior marker followed by the chief moderator who forms part of the examiners for that paper. Umalusi is an independent body responsible for quality assurance of the examination process, including setting of examinations, distribution and authenticating the marking process. They oversee the whole process including the results. They work with the Minister of Education and the rest of the assessment team. This process involves only Grade 12. Amongst other responsibilities, Umalusi standardises the examination to 
Table 3. Physical Sciences results since 2013 for the North West province

\begin{tabular}{|c|c|c|c|}
\hline & & \multicolumn{2}{|c|}{ Physical Sciences } \\
\hline & Year & $\begin{array}{c}\text { No. of } \\
\text { candidates }\end{array}$ & $\begin{array}{c}\% \text { of } \\
\text { candidates }\end{array}$ \\
\hline & Wrote & 8191 & \\
\hline \multirow[t]{2}{*}{ Nov. 2014} & Pass at $30 \%$ & 5243 & $64.01 \%$ \\
\hline & Pass at $40 \%$ & 3012 & $36.77 \%$ \\
\hline Difference & Wrote & -787 & \\
\hline Nov. 2013 \& & Pass at $30 \%$ & -1443 & $-10.46 \%$ \\
\hline \multirow[t]{2}{*}{ Nov. 2014} & Pass at $40 \%$ & -1170 & $-9.81 \%$ \\
\hline & Wrote & 9090 & \\
\hline \multirow[t]{2}{*}{ Nov. 2015} & Pass at $30 \%$ & 5639 & $62.04 \%$ \\
\hline & Pass at $40 \%$ & 3265 & $35.92 \%$ \\
\hline Difference & Wrote & +898 & \\
\hline Nov. 2014 \& & Pass at $30 \%$ & +396 & $-1.97 \%$ \\
\hline \multirow[t]{2}{*}{ Nov. 2015} & Pass at $40 \%$ & +253 & $-0.58 \%$ \\
\hline & Wrote & 8593 & \\
\hline \multirow[t]{2}{*}{ Nov. 2016} & Pass at $30 \%$ & 5984 & $69.64 \%$ \\
\hline & Pass at $40 \%$ & 3699 & $43.05 \%$ \\
\hline Difference & Wrote & -497 & \\
\hline Nov. 2015 \& & Pass at $30 \%$ & +345 & $+7.60 \%$ \\
\hline Nov. 2016 & Pass at $40 \%$ & +434 & $+7.16 \%$ \\
\hline
\end{tabular}

Source: North West Provincial examination analysis report 2017

mitigate the effect of factors other than learners' knowledge and aptitude on the learners' performance and finally approves the results (Umalusi, 2014, p. 84). After approving the results, Umalusi issues the National Senior Certificate to successful candidates. The body consists of academics from various institutions of higher learning such as universities, colleges and Department of Basic Education (DBE) officials.

The Physical Sciences and Life Sciences results of 2012-2016 Grade 12 final examinations are not good. Table 3 shows the Physical Sciences results since 2013 for the North West province.

From Table 3, the quantity of passes is determined by the number of candidates who made the $30 \%+$ pass percentage and the quality passes are determined by the candidates who achieved $40 \%+$ pass percentage. The $30 \%$ and $40 \%$ pass percentage is controversial; however, this is a South African standard outlined in the National Policy Pertaining to the Programme and Promotion Requirements of the National Curriculum Statement policy document (Department of Basic Education, 2013). As can be seen from Table 3, in 2016, in Physical Sciences 497 fewer candidates wrote the subject examination. According to Lehari (2017), Physical Sciences showed an excellent performance as $345(7.60 \%)$ more candidates managed to reach the $30 \%$ pass criteria and $434(7.13 \%)$ more candidates managed to achieve at $40 \%$. There has been debate within the South African education context on the Grade 12 subject pass mark being pegged at 40+\% (Jansen, 2014). Some academics and teachers are overtly against the idea of giving a cut-off point of $40 \%$ as a pass. For example, Muller (2014) contended that pegging the pass mark at $40+\%$ is setting the bar too low. Each year, the Minister for Basic Education produces a strong defence about why the pass mark should be retained and maintained at $40 \%$ and not pushed to $50 \%$ or more (BusinessTech, 2018). The Minister's argument is premised on the National Development Plan (NDP) which directs the Department of Basic Education to mediate the high drop-out rate of learners from the basic schooling system by increasing learner retention rate (Wicks \& Raborife, 2017). Dropping out from high school is associated with negative employment and life chances (Muennig, 2006). Young people who drop out of high school are unlikely to have the minimum skills and credentials necessary to function in today's increasingly complex society and technology-dependent workplace (Christle, Jolivette, \& Nelson, 2007). The completion of high school is required for accessing postsecondary education and is a minimum requirement for most jobs (Child Trends Databank, 2015). Negative outcomes, such as drop-out status have been linked with poor health, including poor mental health along with diminished labour force participation, exerting a high economic toll on society (Muennig, 2006). A country would not want to see itself with a multitude of citizens who dropped out of school: so, political demands and whims have taken the lead and have advocated for $40+\%$ as a pass, however educationally unsound this might be. From a political standpoint, this trend suggests an improvement focusing on the 2016 class, but from an academic viewpoint, the quality of passes raises serious concerns about the competencies and skills the candidates exhibit. Life Sciences generally have similar profile.

There is a myriad of reasons behind such unsatisfactory performance, outlined by several researchers (Ferreira, 2011; Kriek \& Grayson, 2009; Ramnarain \& Fortus, 2013). It is not the purpose of this paper to get entangled in the enumeration of these reasons, but rather to explore the body of knowledge on the use of a 'working' strategy in 
Life Sciences and Physical Sciences which could assist in triggering learners' understanding of difficult concepts, thereby constructing new knowledges as learners interact with one another and the subject content. Scott, Mortimer and Ametller (2011) noted that teachers need to be experts in the subject matter for the successful implementation of teaching and learning processes and the development of scientific conceptual knowledge. Teachers need to be acquainted with new and innovative teaching approaches that not only prepare learners for examinations, but also foster the growth of scientific conceptual knowledge (Jeff, Marshal, Smart, \& Alstone, 2017). Routine and superficial approaches explain why South African learners are not performing well in Physical Sciences when compared with international benchmarks (Lehesvuori, Ramnarain, \& Viiri, 2017). Instructional practices are often classified into two types - teacher-directed or constructivist - depending on whether it is the teacher (direct instructional practices) or the student (constructivist teaching practices) who plays the pivotal role in the learning process (Isac et al., 2015). The notion of a working strategy falls into the latter. This kind of pedagogic practice is characterised by weaker classification and framing, and logic of acquisition as a more progressive (learner-centred) 'invisible' pedagogy (Bernstein, 2000, p. 110). This paper reports on how role-playing was identified as the 'working' teaching and learning strategy.

\section{LITERATURE REVIEW}

\section{Role-playing as a Teaching Strategy}

Role-play is a pedagogical practice that has been used in a wide variety of contexts and content areas (Rao \& Stupans, 2012). Derived from psychodrama, Craciun (2010) explained that role-playing could be used to help learners understand more subtle aspects of literature, social studies, and even some abstract aspects of science or mathematics. Role-playing is a basic engagement and should not be considered just as fun but as part of the learning process (de Medeiros-Silva, de Oliveira, \& de Oliveira, 2017). Thus, role-playing as a basic engagement becomes a forum for learning and mastery of concepts. The school environment needs to be part of a social context that should provide meaningful, pleasurable and dialogical learning, encouraging learners to actively participate in the development of their own mastery of concepts (de Medeiros-Silva et al., 2017). Most of the studies on role-playing we cite in this section, though not from Africa, are from comparable developing contexts. Examples include de Medeiros-Silva et al. (2017, Brazil), Fogg (2001, Malaysia), and Khiri and Mohammadi (2016, Iran). Exceptional cases are the studies done by Bhattacharjee (2014, US), and Westrup and Planander (2013, Sweden). Our focus in such studies was mainly the benefits of using role-playing and we aimed at establishing if similar benefits could be realised in an African context using these pedagogic practices in the teaching of science subjects.

Fogg (2001) reported that learning through play raises learner interest in the topic. According to Poorman (2002), "integrating experiential learning activities in the classroom increased interest in the subject matter and understanding of course content" (p. 32). Learning through play provides the learners with the opportunity to construct knowledge in an interactive and participatory manner. New methods for teaching that incorporate play in order to improve both teaching and learning are seen by some as imperative (de Medeiros-Silva et al., 2017). Role-playing is a teaching strategy that fits within social family models (Joyce \& Weil, 2000); part of this strategy is to emphasize the social nature of learning and promote cooperative behaviour as stimulating learners both socially and intellectually. Fogg's (2001) study also found that there is increased involvement on the part of the learners in role-playing lessons.

Westrup and Planander (2013) summarized the benefits as getting "students to apply their knowledge to solve a given problem, to reflect on issues and the views of others, to illustrate the relevance of theoretical ideas by placing them in a real-world context, and to illustrate the complexity of decision-making" (p.7). Craciun (2010) listed more benefits of using role-play pedagogy as developing the skills of initiative, communication, problem-solving, selfawareness, working cooperatively in teams, and teaching abstract phenomena in physics. During learning through role-play lessons, learners take an active part rather than being passive recipients of the instructor's knowledge. Poorman (2002) observed that "true learning cannot take place when students are passive observers of the teaching process" (p. 32). Besides being an active teaching strategy that promotes skill-based learning, Knowles, Holton, and Swanson (2011) asserted that role-playing as experiential learning offers a high degree of flexibility, creativity, and direct hands-on opportunity in the learning environment. Beyond learning the mere facts of the subject, role-play helps learners to be prepared in dealing with the challenges of the twenty-first century. Poorman (2002) also found "a significant increase among students in feeling another's distress as their own" (p. 34). Role-play has also been effective in reducing racial prejudice in plural societies (McGregor, 1993). Learning through play improves interpersonal skills, communication skills and enhances communication (de Medeiros-Silva et al., 2017). When used in a school setting, learning through play allows learners to extend their knowledge of a subject by researching the concept within a given topic. Using it as a teaching strategy which defines teachers' instructional practices, science teachers can came to realize that they are not just knowledge transmitters but facilitators who allow children to question, investigate and interact. 
Although it is not a new strategy, role-playing has found a privileged place in only a few classrooms in which planning for role-play is a priority for the teacher (Rao \& Stupans, 2012). Role-playing has been used as a pedagogical approach for many years, predominantly in sports education, theatre, history and other social science disciplines. Slowly, role-playing as a holistic teaching method that inculcates critical thinking, stimulates emotions and engenders moral values, and informs about factual data has found its way into the teaching of science subjects (de Medeiros-Silva et al., 2017). Khiri and Mohammadi (2016) found role-playing as a catalyst for problem-based learning which increases decision-making, interpretation and critical thinking. These are essential skills for learners who study science subjects. Using it as a teaching strategy which defines teachers' instructional practices, science teachers need to realize that they are not just knowledge transmitters but facilitators who allow children to question, investigate and interact. Bhattacharjee (2014) summed it all by noting that role-playing increases the efficacy of the learning experience, increases reliability of learners, thus enabling learners to think freely and deeply in a fashion that is more grounded in reality. There are quite a number of reasons why the focus of this paper is on role play as a working strategy for these two science subjects. According to Bhattacharjee (2014) role play provides learners an opportunity to build on their communication skills as well as synthesize the knowledge they have been taught and apply it. Being an active learning model, role-playing teaching encourages the learners for increased involvement. Zenda (2017) asserted that most South African schools (especially the ones in rural areas) do not have teaching and learning materials for science subjects. Strategies have to be established to self-motivate science teachers who have exposure to new teaching methods in science subjects. Zenda further states that strategies which need to stimulate scientific curiosity in learners through direct or indirect investigations of the natural phenomena in their immediate environments should be identified. It is therefore important that flexible teaching methods should be adapted to the needs of individual learners, hence role play was identified in this paper as the teaching strategy, following from Zenda's proposition.

In South Africa, role play is not new but has been used mainly in secondary schools as a tool to teach drama as Arts and Culture subject (Moore \& Lemmer, 2010). Arts and Culture is a school subject in South African curriculum taught in Grades 4 to 9 to primary and middle school learners. In the South African context, role play is used in kindergartens and to teach all the subjects offered in primary schools. According to Bhattacharjee (2014) there is a dearth of studies where role play is used in high schools. Thus, this paper tries to create awareness that this strategy can be used in the high the school teaching, particularly in science subjects. In European countries, for example, role play has been used in behaviour change (Kaloyirou \& Lindsay, 2014), in teaching science topics such as analytical chemistry where learners have been reported to have acquired a good understanding of the workings of the analytical technique through role-playing as parts of a mass spectrometer (Perry, 2007; Rao \& Stupans 2012). In this context, role-play aligns with concepts for motivating learning approaches, with possibilities for capturing student attention and through emphasis of the relevance of the tasks in debrief. There are also acknowledged benefits for learners of approaching ideas from multiple perspectives (Merrill, 2002). In sum, it can be inferred that role-playing has not been used much in the South African context in secondary schools when compared to other third world countries such as Brazil and European countries. In European countries, role-play is considered to be effective in achieving a broad range of learning outcomes, and is indeed able to address cognitive, affective and psychomotor domains of learning as described in Bloom's taxonomy (Rao \& Stupan, 2012). In the South African context, not much effect of role-playing in secondary schools has been reported. The paper reports on the aha! moment (a point in time when the teachers had sudden insight into a 'working' teaching and learning strategy), to improve and sustain learner performance in the two subjects that are perceived to be difficult by learners and where performance is below the national average in a majority of schools in the North West province.

\section{Research Questions}

The central research question is: What spawned the aha! moment for the teachers during the teaching and learning process, in their bid to improve and sustain learner performance? The focus of this question is limited to four teachers of the best-performing schools in the two subjects perceived difficult by learners. Two sub-questions which the study focuses on are: (i) What is the relevance of role playing as the identified strategy in practice? (ii) How does role play in practice relate to teachers' pedagogic practices?

\section{Conceptual Framework}

Ausubel's (1963) constructs of Meaningful Reception Learning theory provided the conceptual framework for this study. There are other theoretical or conceptual frameworks which could have been used, where the learner is embedded in the teaching and learning process. However, this framework was adopted because it points to the overarching principle that learning from instruction requires learners to play an active role in order to acquire new knowledge successfully (Shuell, 1988). The knowledge gained through meaningful learning applies to a new learning situation. Meaningful learning is active, constructive and long-lasting, but most importantly it allows student to be fully engaged in the learning process. Thus, it stays with learners for life. Reception learning 
Table 4. Ausubel's Model of Meaningful Learning

\begin{tabular}{lll}
\hline Phase One & Phase Two & Phase Three \\
Advance Organiser & Presentation of Learning task or Material & Strengthening Cognitive Organisation \\
\hline Clarify aim of the lesson & Make the organization of the new material explicit & Relate new information to advance organiser \\
\hline Present the lesson & Make logical order of learning material explicit & Promote active reception learning \\
\hline $\begin{array}{l}\text { Relate organiser to } \\
\text { students' prior knowledge }\end{array}$ & $\begin{array}{l}\text { Present material in terms of basic similarities and } \\
\text { differences by using examples and engage students } \\
\text { in meaningful learning activities }\end{array}$ & \\
\hline
\end{tabular}

Source: Adapted from Ausubel (1968)

essentially means that learners receive information, think about it, make deductions and then apply such information to resolve a contentious problem. Within a classroom setting, this cognitivist theory brings about a holistic and collaborative learning and teaching approach. According to Haas and Parkay (1993), information is said to be meaningful if "it can be related in some way to the learners' present, past or future experiences" (p. 144). Ausubel contended that learning occurs because of the relatedness of what learners know and what they learn. In other words, learning proceeds in a deductive manner. For this study, Ausubel's learning model was coupled with role-play as a learner-centred pedagogy. Ausubel's theory consists of three phases and the main elements of Ausubel's teaching method are shown in Table 4.

Ausubel (1968) advocated the use of advance organisers to help link new learning material with existing related ideas and constructs. An advance organiser is information presented by an instructor (in this case a teacher) that helps the learner organise new incoming information (Mayer, 2003). This is achieved by directing attention to what is important in the coming material, highlighting relationships and providing a reminder about relevant prior knowledge (Woolfolk, Winne, Perry, \& Shapka, 2010). Advance organisers make it easier to learn new material of a complex and difficult nature, provided the learner processes and understands the information presented in the organiser (Kumagai, 2013; Woolfolk et al., 2010), as this increases the effectiveness of the organiser itself. Furthermore, the organiser must indicate the relations among the basic concepts and terms that shall be used. Ausubel distinguished between two kinds of advance organisers, comparative and expository. Comparative organisers act as reminders to bring into the working memory of what one may not realise as relevant. In contrast, "expository organisers provide new knowledge that students would need to understand the upcoming information" (Woolfolk et al., 2010, p. 289). Essentially, expository organisers furnish an anchor in terms that are already familiar to the learner. As mentioned earlier, coupled with role-play, as the practice of having learners take on specific roles - usually roles they are not familiar with - and act them out in a case-based scenario for the purposes of learning course content and understanding "complex or ambiguous concepts" (Sogunro, 2004, p. 367).

\section{METHODOLOGY}

The study was purely qualitative, thus employed exploratory case-study approach. According to Saunder, Louise and Thornhill (2012) exploratory research is conducted in order to determine the nature of the problem but merely explores the research topic with varying levels of depth. Exploratory research also "tends to tackles new problems on which little or no previous research has been done" (Singh, 2007, p. 64). For these reasons, an exploratory case study was adopted, which according to Basit (2010), supports the production of detailed accounts and deeper consideration of actions, experiences and perceptions.

\section{Sample}

Participants. The sample consisted of four Further Education and Training (FET) teachers of two best-performing public high schools and one of their Grade 12 classes. Since 2013, both schools have had a 100\% pass rate in Life Sciences. This is high compared to $70.4 \%$ national pass rate for Life Sciences. For Physical Sciences both schools have had a minimum of a $98 \%$ pass rate. This is high compared to the national pass rate of $58.6 \%$ for Physical Sciences. Regarding the quality of learner performance, at both schools and in Life Sciences, the average score is $78 \%$; for Physical Sciences, the average score is $75 \%$. Comparing the Physical Sciences average score of these two schools and the ones on Table 3, it can be inferred that these two schools are performing well. Each school had one Grade 12 class specialising in Physical Sciences and one class specialising in Life Sciences. The other classes specialised in other subjects such as History, Geography and Accounting. Table 5 summarises the distinct features of the two schools in this study. 
Table 5. Summary of the distinct features of School A and School B

\begin{tabular}{|c|c|c|}
\hline Features & School A & School B \\
\hline $\begin{array}{l}\text { Distance from researchers' area } \\
\text { (Mmabatho) }\end{array}$ & $\begin{array}{l}60 \mathrm{~km} \text { in the outskirts of the capital city of the } \\
\text { province in a small town. }\end{array}$ & $\begin{array}{l}\text { Within the capital city of the } \\
\text { province in a suburban area. }\end{array}$ \\
\hline Subject group & \multicolumn{2}{|c|}{$\begin{array}{c}\text { Physical Sciences } \\
\end{array}$} \\
\hline Teacher's population group & White & Black \\
\hline Teacher's pseudonym & Natalie & Modise \\
\hline Teacher's gender & Female & Male \\
\hline Age & 33 & 44 \\
\hline Number of learners in class & 26 & 33 \\
\hline Learners' gender & 12 males and 14 females & 18 males and 15 females \\
\hline Learners' population group & 8 Black, 12 White and 6 Indians & 33 Black \\
\hline Subject group & \multicolumn{2}{|l|}{$\begin{array}{ll}\text { Life Sciences } \\
\end{array}$} \\
\hline Teacher's population group & White & Black \\
\hline Teacher's pseudonym & Lizanne & Kelebogile \\
\hline Teacher's gender & Female & Female \\
\hline Age & 47 & 43 \\
\hline Number of learners in class & 32 & 36 \\
\hline Learners' gender & 19 males 13 females & 14 males and 22 females \\
\hline Learners' population group & 10 Black, 15 White and 7 Indians & 36 Black \\
\hline
\end{tabular}

The two schools sampled had moderate class sizes. The Life Sciences classes had 32 and 33 learners whilst the Physical Sciences had 25 and 26 learners. In South Africa, the majority of classes are overcrowded with up to 55 learners in a class which is beyond the national Department of Education's teacher to learner ratio. Thus, the two schools in the study are described as having moderate class sizes. All the four teachers had a Bachelor's teaching degree in either Physical Sciences or Life Sciences. Natalie was studying towards an Honours degree in Physical Sciences and Kelebogile had completed her Honours degree in Life Sciences and was now studying towards her Master's degree. The sample was purposively selected from one district of the North-West province of South Africa which was deemed to be performing well and contributing significantly to the overall performance of the province in matriculation examinations. Purposive sampling is a non-probability method whereby only those two schools consistently producing a pass rate of over $90 \%$ were selected.

The Grade 12 learners are between 16 and 18 years of age. The average age for the learners who took part in this study is 17 years. The teachers were purposively sampled and each teacher had one Grade 12 class. This group of learners became automatically purposefully sampled. Fortunately enough, all parents and the learners gave consent to take part in the study as these was a provincial Department of Basic Education's (DBE's) intervention programme. This was a study requested by the Department of Basic Education, after it had issued ethical clearance. One of the Grade 12 Physical sciences class has 25 learners (12 males and 13 females). Of the 25 learners, 12 were Black ( 4 male and 5 females), 8 were White ( 4 males and 6 females) and 5 were Indians ( 4 female and 2 males). The other Physical Science class had 26 learners. All the 26 learners were Black (10 males and 16 females). For Life Sciences, one of the Grade 12 classes had 32 learners (14 males and 18 females). Of the 32 learners 10 were Black ( 3 males and 7 females), 14 were White ( 6 males and 8 females) and 8 were Indians ( 5 males and 3 females). The other Life Science class had 32 learners. All the 32 learners were Black (12 males and 20 females).

\section{Research Methods}

In order to capture the lived experiences, perspectives and knowledge generated by the four teachers - Natalie, Lizanne, Kelebogile and Modise - classroom observations and semi-structured interviews as 'extended conversations' (Holland \& Ramazanoglu, 1995) were organised on a regular basis (one interview per three weeks) over a school term period (three months) resulting in sixteen interviews (four with each teacher) in all. The learners for each class were interviewed twice, immediately after the first and last classroom observation sessions. Learners' interviews took the form of focus-group interviews with five learners in each group. Both teachers were asked to randomly select any five learners from the participating class. Teachers purposively selected the learners, targeting those who could express themselves confidently. The focus was on how learners viewed the role-playing teaching strategy and its relevance in their learning process. Natalie, Lizanne, Kelebogile and Modise aimed to sustainably improve learner performance (in tests and the examination), protect time for teaching and learning, improve support for teaching and learning and increase effort on time-on-task as these were areas of difficulty which most significantly impacted on learners' success. These are also DBE's 2015 National Strategy for Learner Attainment (NSLA) framework objectives. Learners' work samples, photographs and comments provided sources of additional 
Table 6. Three stages of coding

\begin{tabular}{|c|c|c|}
\hline $\begin{array}{l}\text { Stages of } \\
\text { Coding }\end{array}$ & Type of coding & Process involved \\
\hline First stage & Open coding & $\begin{array}{l}\text { Initial themes and codes were assigned to the data in order to condense the mass of data } \\
\text { into categories. Codes were identified based on questions from the diary entries, observation } \\
\text { schedule and interview schedule, which were designed with the research question in mind }\end{array}$ \\
\hline Second stage & Axial coding & The codes were organised, linked and key analytical categories discovered \\
\hline Third stage & Selective coding & $\begin{array}{l}\text { Previous codes were examined to identify and select data that would support the conceptual } \\
\text { coding categories previously developed }\end{array}$ \\
\hline
\end{tabular}

Source: Adapted from Neuman (2011)

Table 7. Table displaying techniques this study used to establish trustworthiness

\begin{tabular}{lll}
\hline $\begin{array}{l}\text { Aspects of } \\
\text { trustworthiness }\end{array}$ & Criteria & $\begin{array}{l}\text { Techniques used to achieve } \\
\text { trustworthiness }\end{array}$ \\
\hline Credibility & Confidence in the 'truth' of the findings & Triangulation through multiple data sources \\
\hline \multirow{2}{*}{ Transferability } & $\begin{array}{l}\text { Showing that the findings have applicability in other } \\
\text { contexts }\end{array}$ & $\begin{array}{l}\text { Thick description of empirical evidence based on } \\
\text { details of the schools }\end{array}$ \\
\hline Dependability & $\begin{array}{l}\text { Showing that the findings are } \\
\text { consistent and could be repeated }\end{array}$ & $\begin{array}{l}\text { Maintaining an audit trail and the use of quotes } \\
\text { to discuss findings }\end{array}$ \\
\hline Confirmability & $\begin{array}{l}\text { Extent to which the findings are shaped by the respondents } \\
\text { and not researcher bias, motivation or interest }\end{array}$ & $\begin{array}{l}\text { Maintaining an audit trail and the use of quotes } \\
\text { to discuss findings }\end{array}$ \\
\hline Source: Adapted from Lincoln and Guba (1985) &
\end{tabular}

Source: Adapted from Lincoln and Guba (1985)

and complementary data. Thus, data was generated through interviews, classroom observations and document analysis.

\section{Data Analysis}

Open coding, axial coding and selective coding were used to thematically analyse the data (Neuman, 2011), as shown in Table 6. This analysis was guided by an analytical tool which was derived from the conceptual framework. For example (Table 4), in the phase three construct, 'promote active reception learning', the analytical tool had points such as: focus on discovery and exploitation, student-centred, high collaboration amongst others. For phase one, the construct 'clarify aim of the lesson' on the analytical framework focused on an analogue as an introduction, stating of lesson objectives or emphasising on the purpose for the lesson amongst others. This helped organise data into conceptual categories and themes whilst also assisting in the development of several core generalisations. This was then used to identify patterns across data and develop tentative explanations. Patternmatching assisted in making comparisons (Schwandt, 2001) and looking for outliers (Yin, 2003), thereby assisting in a better understanding and analysis of data. The results of the study demonstrate the effort these four teachers put in to establish a 'working' strategy of teaching that resulted in improvement and sustained learner performance in Life and Physical Sciences.

The three stages of coding are shown in Table 6.

\section{Trustworthiness}

Lincoln and Guba's (1985) concept of trustworthiness was used to strengthen the quality of findings and enhance trustworthiness of the study. The four aspects of trustworthiness are described in Table 7. The following was done to show the validity of the data obtained. To ensure credibility, triangulation through multiple data sources such as, classroom observation, interviews and analysis of learning materials were used. Thick description of empirical evidence, based on details of the schools, was used to ensure transferability. Maintaining an audit trail and the use of quotes of participants' responses in verbatim to discuss findings ensured dependability. We maintained an audit trail by utilising the peer debriefing and support strategy to ensure that the quotes used to discuss findings were accurate.

As shown on Table 8, in the first phase, advance organisers, three themes with two codes for each theme were generated, giving a total of six codes. For the first phase, the three quotes were selected from both teachers and learners on the condition that at least all the six codes were represented in the quotes. The second phase, relating to presentation of learning task or material, also had three themes. Like the first phase, two codes were generated for each theme. However, for the learners, only two quotes were selected. The rationale for the selection was grounded on the fact that the two quotes were inclusive of all six codes. The third phase relating to strengthening cognitive organisation had two themes and each theme had two codes. Five quotes were selected, one from a learner and one from each of the four teachers. In a way, the quotes were selected on the basis of how each teacher explained 
Table 8. Examples of themes and codes

\begin{tabular}{|c|c|c|}
\hline Phase & Themes & Codes \\
\hline \multirow{5}{*}{$\begin{array}{l}\text { Phase } 1 \\
\text { Advance } \\
\text { organiser }\end{array}$} & clarifying the aims of the lesson & $\begin{array}{l}\text { i. Trial and error; I like trying new teaching methods (teacher interview) } \\
\text { ii. Teacher giving direction to the lesson (observation) }\end{array}$ \\
\hline & presenting the lesson, and & $\begin{array}{l}\text { i. Teacher states aim and asked learners to group themselves (observation) } \\
\text { ii. learners prepare and present the coming lessons using role-playing } \\
\text { (teacher interview) }\end{array}$ \\
\hline & relati & $\begin{array}{l}\text { i. role-playing in a way they understood the new incoming information } \\
\text { (observation) }\end{array}$ \\
\hline & prior kno & $\begin{array}{l}\text { ii. prior knowledge was used as a basis of what the learners were doing } \\
\text { (observation) }\end{array}$ \\
\hline & human experie & ence of suddenly understanding a previously incomprehensible problem \\
\hline \multirow{4}{*}{$\begin{array}{l}\text { Phase } 2 \\
\text { presentation of } \\
\text { learning task or } \\
\text { material }\end{array}$} & $\begin{array}{l}\text { making the organisation of the } \\
\text { new material explicit }\end{array}$ & $\begin{array}{l}\text { i- teacher prepares ahead for us and we play a game based on the topic } \\
\text { she has to teach (learner interview). } \\
\text { ii- we act role assigned, e.g. in electricity if you are a conductor, you will } \\
\text { have to behave like a messenger (learner interview). }\end{array}$ \\
\hline & $\begin{array}{l}\text { making logical order of learning } \\
\text { material explicit, }\end{array}$ & $\begin{array}{l}\text { i- play (act the path of current flow when it is connected in parallel or in } \\
\text { series) opened my mind rather than reading the books or listening in class } \\
\text { all the time (learner interview) } \\
\text { ii- learners apply all their skills in a realistic, nonetheless safe setting } \\
\text { (learners' work samples) }\end{array}$ \\
\hline & $\begin{array}{l}\text { presenting material in terms of } \\
\text { basic similarities and differences } \\
\text { by using examples, and } \\
\text { engaging students in meaningful } \\
\text { learning activities. }\end{array}$ & $\begin{array}{l}\text { i- learners used simulations first to demonstrate similarities and differences } \\
\text { between parallel and series circuits before a group presenting this topic } \\
\text { offered it through role-playing (observation) } \\
\text { ii- learners had consulted with their teacher during preparation time } \\
\text { (teacher interview) }\end{array}$ \\
\hline & Category: relevance of imagined ic & deas by placing them in a real-world context \\
\hline \multirow{3}{*}{$\begin{array}{l}\text { Phase } 3 \\
\text { Strengthening } \\
\text { Cognitive } \\
\text { Organisation }\end{array}$} & $\begin{array}{l}\text { Relate new information to } \\
\text { advance organiser }\end{array}$ & $\begin{array}{l}\text { i- teacher clarifying certain concepts after group presentations } \\
\text { (observation). } \\
\text { ii- ensuring group presentations were not introducing misconceptions and } \\
\text { also addressing [providing the] missing conceptions (teacher interview). }\end{array}$ \\
\hline & $\begin{array}{l}\text { Promote active reception } \\
\text { learning }\end{array}$ & $\begin{array}{l}\text { i- learners' second language learning enhanced (observation) } \\
\text { ii- ensuring new knowledge was linked to what the learners already knew } \\
\text { and preparing for the learners for the new content (teacher interview) }\end{array}$ \\
\hline & $\begin{array}{l}\text { ry: role-playing is a } \\
\text { learning process }\end{array}$ & ngagement and should not be considered just as fun but as part of the \\
\hline
\end{tabular}

the relevance of the identified strategy in practice. Furthermore, selection of the quotes was envisaged to reveal how the identified strategy in practice related to teachers' pedagogic practices in a bid to improve and sustain learner performance. Each set of codes for each theme formed a set of categories for each phase that summarises the ideas in the codes together.

\section{RESULTS AND DISCUSSION}

In this section we introduce the cases for the two best-performing schools (and their four teachers) by presenting data based on themes around the three phases and main elements of Ausubel's teaching method. Phase one relates to the advance organisers; phase two relates to presentation of learning task or material; and phase three relates to strengthening cognitive organisation. The generated resonances were linked to DBE's (2015) NSLA framework objectives of sustained improvement in learner performance, role of teachers, improved support for teaching and learning, and increased efforts on time on task, making high learner attainment.

The three themes based on the first phase are: clarifying the aims of the lesson, presenting the lesson, and relating the organiser to learners' prior knowledge. With a minimum of at least ten years in their teaching profession, the four teachers had their common human experience of suddenly understanding a previously incomprehensible problem [the aha! moment] through trial and error. This was in a bid to improve learner performance and ensure that they sustain their effort. This study identified what they called a 'working' teaching strategy which is roleplaying. During interviews, the teachers had this to say:

I am a teacher full of energy. I like trying new teaching methods. My learners generally are not that bad but I used to do a lot for them. More-or-less like spoon feeding, you understand ... I just decided someday to try role-playing as a teaching method. I had done an assignment for my Honours 
assignment on it and I really doubted if it would work at FET level. Mine was to give the aim after one of my normal lessons, I asked the learners to put themselves in groups of fours as they were going to prepare and present the coming lessons using role-playing. That is how I introduced it to my learners. My aha! moment was when I put the method to test and it worked when revising the topic electricity (Natalie, School A).

Kelebogile's narration was almost similar to that of Natalie. She says she has a lot of work to do. This is her response:

I attended a Professional Support Forum (PSF) meeting. Then I had an informal chat with a colleague from another school teaching a similar grade. Then she suggested to me this teaching method to me. I told her openly that it was possibly going to work with lower grades, for example, kindergarten. She told me to try it. When I got to school, I asked my learners to role-play the lesson on body organs and show how they maintain a constant body temperature (Kelebogile, School B).

One of Kelebogile's learners had this to say during focus-group interviews: "Playing Pancreas helped me to actually understand how this organ contribute in regulating blood sugar level. My friend was "Liver" and I can never forget how I and her worked together to maintain the internal body environment".

As can be inferred from the learner's description of events in the role-play lesson, the presentation of the lessons is solely the responsibility of the learners. Interestingly, the advance organiser was just clarifying aims of the lesson by the teacher and giving direction to the lesson (Kumagai, 2013). The rest was left to the learners to use role-playing in a way they understood the new incoming information. In a way, all the learners were doing was related to their prior knowledge. This is related to the comparative organiser (Woolfolk et al., 2010).

The second phase, presentation of learning task or material, had three themes. These are: (1) making the organisation of the new material explicit; (2) making logical order of learning material explicit; and (3) presenting material in terms of basic similarities and differences by using examples, and engaging students in meaningful learning activities. All four teachers planned for the lessons well, making sure that the new material to be taught was made explicit. This is what one learner from Modise's class said during a focus-group interview:

Our teacher prepares ahead for us to play a certain game based on the topic she has to teach. One time she came to class with soccer/ netball balls pasted with instructions to follow. She threw the ball randomly at anyone, when you catch the ball you have to act what is written and the whole class will follow and identify what part of the topic you are acting or simply who you are and your role, for example in electricity if you are a conductor, you will have to behave like a messenger. Taking current from the source of energy to the appliance stated. My friend was a radio (laughed), and it was such fun (Learner 1, Modise's class, School B).

Logical order of learning material was made explicit. A second learner from Modise's class had this to say:

We also had to act the path of current flow first when it is connected in series. The way the current flows was well explained during role play and discussion time. After the series circuit, role play moved to parallel circuit illustrating the way in which current flows. In both instances the effect of resistance when high or low was discussed. That was a play that opened my mind rather than reading the books or listening in class all the time (Learner 2, Modise's class, School B).

Regarding presenting material in terms of basic similarities and differences by using examples, and engaging learners in meaningful learning activities, the role-playing teaching employed by teachers facilitated it well. As witnessed during classroom observations of Modise's lessons on electricity, the learners used simulations first to demonstrate similarities and differences between parallel and series circuits before a group presenting this topic offered it through role-playing. However, it was evident that the group learners had consulted with their teacher during preparation time. In a way the learning process was significantly dependent on the teachers as also shown by Kumagai (2013).

Two themes were formulated from the third phase dealing with strengthening cognitive organisation. The two themes are; relating new information to an advance organiser and promoting active reception learning. The first theme can be illustrated by what was observed in Lizanne's classes. Lizzane could be seen following sessions where learners had role-played with keen interest. She was also seen clarifying certain concepts after group presentations. Asked why she was doing that during interviews, she had this to say:

I wanted to make sure that group presentations were not introducing misconceptions and also addressing [providing the] missing conceptions. So, I was trying to concretise what the learners were already familiar with. Given that group presentations were more or less like play but serious content 
delivery, I wanted to ensure that in a way I was emphasising how relevant this information was for the learners to remember. In a nutshell, I was ensuring new knowledge was linked to what the learners already knew and preparing for the learners for the new content which was yet to be presented in future.

This finding confirms de Medeiros-Silva et al. (2017) findings which showed that role-playing is a basic engagement and should not be considered just as fun but as part of the serious learning process.

Having sat in all four teachers' classrooms during teaching and learning sessions, a question asked to all four teachers towards the end of the study was "what is the use and relevance of role-play in practice?" Natalie responded:

By simulating a scenario during acting [and] role-playing, it allows my learners to practise newly developed skills where that skill may be required which is close to the real experience of the learners. Learners' second language learning is enhanced, and it motivates them to research for specific topics.

Lizanne's response to the question was:

During role-playing, learners apply their knowledge to a given problem and at the same time illustrate relevance of imagined ideas by placing them in a real-world context through reflecting on issues and the views of others. There is however a point I would like to make clear, as part of the paramount practices, as a teacher, I think deeply about the learning goals of the role-play and choosing a case that best reaches those goals.

Modise's response was skewed towards that of Lizanne. He said,

The teacher just like the learners has to be adequately prepared with instance materials and familiar with the pedagogy. The learners apply all their skills in a realistic, nonetheless safe setting. However, I would [like] to point out that as you saw me doing, I allowed for sufficient and appropriate feedback and debriefing of the entire exercise. This is so important if use of this method has to be a success.

Kelebogile responded to the question by saying,

All I can say is that through use of this method, learner interest in the topic is raised, there is increased contribution on the part of the learners in role-playing lessons and learners use their background knowledge in addition to acquiring new information. I must however, point out that, a teacher needs to have about both the content and the pedagogy because the amount of time taken to properly prepare for the lessons and the amount of knowledge is quite a lot. If one takes time to prepare, indeed the benefits far outweigh the effort.

This also affirms Khiri and Mohammadi's (2016) observations, which showed that role-playing is a method of problem-based learning which increases the ability of learners in decision-making, interpretation of situation and critical thinking.

An inference can be made from the teachers' responses to questions posed and recollecting some events which took place during the teaching and learning process, in answering a question such as, how does role-play in practice relate to your teachers' practices? What is clear is that the teachers do know the pros and cons of such a teaching strategy. For example, Kelebogile said,

Role-playing for me is a make-up procedure, and improvisation which requires a feeling of relative safety for the learner. The teacher engaging learners in groups, should ensure that they get to know each other in a more trusting fashion and become involved in the theme [or topic] to be learned. The introduction is more important. I can use the analogy of a surgeon knowing how to prepare a patient for an operation. Otherwise, it will be play for the sake of play.

\section{CONCLUSIONS}

From the results presented and discussed, the eureka effect (aha! moment) was that moment when all four teachers who took part in this study identified role-playing as a teaching and learning strategy amongst other strategies chosen to bring about a desired future, such as achievement of a goal or solution to a problem. In this study, the desired future was to improve and sustain learner performance by the four teachers of the bestperforming schools in both Life and Physical Sciences, two subjects perceived difficult by learners who perform on the average to low in a majority of schools in the North West province. Another finding was that teachers were well-informed regarding the use and relevance of role-play in practice. Learner interest in the topic was evidently raised as was observed in the case study. There was also increased contribution on the part of the learners in role- 
playing lessons and learners' use of their background knowledge in addition to acquiring new information. Phases of the conceptual framework were evoked in describing the findings. Play in practice was related to teachers' pedagogic practices by emphasising the fact that planning is important, just like the introduction where the aims of the lesson are clarified. This study demonstrated that constructs of Ausubel's Meaningful Reception Learning theory were coupled with role-playing to describe the experiences of teachers in narrating their teaching practices.

\section{RECOMMENDATIONS}

The study recommends that teachers who are keen to establish uncommon teaching practices, such as the ones in this study, should share them with their colleagues who are in schools which are not doing as well as them. Further research could be done when teachers, such as the ones described in this study, are paired with their colleagues from poor-performing schools for improved results in the latter. The study also recommends that curriculum designers attach certain teaching strategies to some topics in the policy documents for the teachers to implement. This may assist teachers who might not be aware that certain teaching strategies such as role-play may be the answer in topics that they struggle to impart successfully. Lastly, it is also recommended that education planners should focus on encouraging and updating teachers' classroom practices by all possible means. This might gradually create a ripple effect on improving learner performance in science subjects.

\section{REFERENCES}

Ausubel, D. (1963). The psychology of meaningful verbal learning. New York: Grune \& Stratton.

Ausubel, D. P. (1968). Educational psychology: A cognitive view. New York, NY: Holt, Rinehart \& Winston, Inc.

Basit, T. (2010). Conducting research in educational contexts. London: Continuum International Publishing Group.

Bernstein, B. (2000). Pedagogy, symbolic control and identity: Theory, research, critique (revised edition.). London: Rowman \& Littlefield.

Bhattacharjee, S. (2014, March). Effectiveness of roleplaying as a pedagogical approach in construction education. Paper presented at the 50th Annual Meeting of the Associated Schools of Construction (ASC), Washington, DC. Retrieved from http:/ / ascpro0.ascweb.org/archives/cd/2014/paper/CERT199002014.pdf

BusinessTech (2018). The worrying truth behind SA's 'improved' maths and science marks. Retrieved from https:/ / businesstech.co.za/news/lifestyle/218275/the-worrying-truth-behind-sas-improved-maths-andscience-marks /

Child Trends Databank. (2015). High school dropout rates. Retrieved from https://www.childtrends.org/?indicators=high-school-dropout-rates

Christle, C. A., Jolivette, K., \& Nelson, C. M. (2007). School characteristics related to high school dropout rates. Remedial \& Special Education, 28(6), 325-339. https:/ / doi.org/10.1177/07419325070280060201

Craciun, D. (2010). Role-playing as a creative method in science education. Journal of Science and Arts, 1(12), 175182.

De Medeiros Silva, S. C. G., de Oliveira, M. M., \& de Oliveira, G. F. (2017). Playful teaching work of school science teachers fundamental in a municipal school in Pernambuco, Brazil. Early Child Development and Care, 187(2), 233-243. https:// doi.org/10.1080/03004430.2016.1237565

Department of Basic Education. (2011a). The Curriculum and Assessment Policy Statement (CAPS) Grades 10-12: Physical Sciences. Pretoria: Government printers.

Department of Basic Education. (2011b). The Curriculum and Assessment Policy Statement (CAPS) Grades 10-12: Life Sciences. Pretoria: Government printers.

Department of Basic Education. (2013). National Policy Pertaining to the Programme and Promotion requirement of the National Curriculum statement. Pretoria: Government printers.

Department of Basic Education. (2015). 2015 National Strategy for Learner Attainment. Pretoria: Government Printers.

Department of Basic Education. (2018). 2017 National Senior Certificate Diagnostic Report Part 1. Pretoria: Government Printers.

Ferreira, J. G. (2011). Teaching Life Sciences to English second language learners: What do teachers do? South African Journal of Education, 31, 102-113. https:/ / doi.org/10.15700/saje.v31n1a409

Fogg, P. (2001). A history professor engages students by giving them a role in the action. Chronicle of Higher Education, 48(12), 12-13.

Haas, G., \& Parkay, F.W. (1993). Curriculum planning: A new approach (6th ed.). Boston: Allyn \& Bacon. 
Holland, J., \& Ramazanoglu, C. (1995). Accounting for sexuality, living sexual politics: Can feminist research be valid? In J. Holland, M. Blair, and S. Sheldon (Eds.), Debates and Issues in Feminist Research and Pedagogy, (pp. 273-291). Clevedon: Multilingual Matters Ltd.

Isac, M. M., Dinis da Costa, P., Araújo, L., Soto Calvo, E., \& Albergaria-Almeida, P. (2015). Teaching practices in primary and secondary schools in Europe: Insights from large-scale assessments in education. Fermi: European Commission, Joint Research Centre Retrieved https:/ / crell.jrc.ec.europa.eu/sites/default/files/files/JRC95601.pdf

Jansen, J. (2014, January 12). 24\% of matrics would have passed if pass mark was 50\%. City Press. Retrieved from https:/ / www.news24.com/Archives/City-Press/24-of-matrics-would-have-passed-if-pass-mark-was-5020150430

Joyce, B., \& Weil, M. (Eds.). (2000). Models of teaching. Boston: Allyn and Bacon.

Kaloyirou, C., \& Lindsay, G. (2014). Understanding bullying: using role-play with 12-year- old boys in Cyprus. European Journal of Special Needs Education, 29(2), 153-166. https:/ / doi.org/10.1080/08856257.2014.884828

Khiri, B., \& Mohammadi, E. (2016). Identifying educational methods for developing entrepreneurship and employment at Applied Scientific Centre's of Ilam province. International Journal of Humanities and Cultural Studies, 3(1), 630-639.

Knowles, M. S., Holton, E. F., \& Swanson, R. A. (2012). The adult learner (7th ed.). Burlington, MA: Elsevier, Inc.

Kriek, J., \& Grayson, D. (2009). A holistic professional development model for South African Physical Science teachers. South African Journal of Education, 29, 185-203.

Kumagai, S. N. (2013). Ausubel's subsumption theory: The role and nature of advance organizers. California State University: Monterey $\quad$ Bay. Retrieved from http:/ / www.academia.edu/4865184/Ausubels_Subsumption_Theory_The_Role_and_Nature_of_Advanc e_Organizers

Lee, E., \& Luft, J. A. (2008). Experienced secondary science teachers' representation of pedagogical content knowledge. International Journal of Science Education, 30, 1343-1363. https:/ / doi.org/10.1080/09500690802187058

Lehari, J. S. (2017). Address on the occasion of the release of the 2016 results on 05 January 2017. North West: North West Provincial Government.

Lehesvuori, S., Ramnarain, U., \& Viiri, J. (2017). Challenging transmission modes of teaching in science classrooms: Enhancing learner-centredness through dialogicity. Research in Science Education, https:/ / doi.org/10.1007/s11165-016-9598-7

Lincoln, S. Y., \& Guba, E. G. (1985). Naturalistic inquiry. London: Sage.

Makgato, M., \& Mji, A. (2006). Factors associated with high school learners' poor performance: A spotlight on mathematics and physical science. South African Journal of Education, 26(2), 253-266.

Marshall, J. C., Smart, J. B., \& Alston, D. M. (2017) Inquiry-based instruction: A possible solution to improving student learning of both science concepts and scientific practices. International Journal of Science and Mathematics Education, 15, 777-796. https:/ / doi.org/10.1007/s10763-016-9718-x

Mavhungu A. P. (2004). Factors influencing the performance in agricultural science in some high schools in the Limpopo Province (Unpublished master's thesis). University of Pretoria, Pretoria.

Mavhungu, M. (2016). Complexities and constraints influencing learner performance in physical science. Journal of Research in Business \& Social Science, 5(1), 30-46.

Mayer, R. E. (2003). Learning and instruction. Upper Saddle River, NJ: Merrill.

McGregor, J. (1993). Effectiveness of role-playing and anti-racist teaching in reducing student prejudice. Journal of Educational Research, 86(4), 215-226. https:/ / doi.org/10.1080/00220671.1993.9941833

Moore, J., \& Lemmer, E. (2010). Towards cultural proficiency in South African secondary schools: Ethnodrama as educational tool. Education as Change, 1, 5-18. https:/ / doi.org/10.1080/16823206.2010.487356

Muennig, P. A. (2006). Healthier and wealthier: Decreasing health care costs by increasing educational attainment. Washington, DC: Alliance for Excellent Education. Retrieved from http://all4ed.org/wpcontent/uploads/HandW.pdf

Muller, J. (2014, January 12). 24\% of matrics would have passed if pass mark was 50\%. City Press. Retrieved from https:/ / www.news24.com/Archives/City-Press/24-of-matrics-would-have-passed-if-pass-mark-was-5020150430

Neuman, W. L. (2011). Social research methods: Qualitative and quantitative approaches (7th ed.). Boston, MA: Pearson. 
Perry, E. (2007). Using role-play to model mass spectrometer. School Science Review, 88(324), 18.

Poorman, P. B. (2002). Biography and role-playing: Fostering empathy in abnormal psychology. Teaching of Psychology, 29(1), 32-36. https:/ / doi.org/10.1207/S15328023TOP2901_08

Ramnarain, U., \& Fortus, D. (2013). South African physical sciences teachers' perceptions of new content in a revised curriculum. South African Journal of Education, 33(1), 1-15. https:/ / doi.org/10.15700/ saje.v33n1a573

Rao, D., \& Stupans, I. (2012). Exploring the potential of role play in higher education: Development of a typology and teacher guidelines. Innovations in Education and Teaching International, 49(4), 427-436. https:/ / doi.org/10.1080/14703297.2012.728879

Saunders, M., Lewis, P., \& Thornhill, A. (2012). Research Methods for Business Students (6th ed.). Harlow, UK: Pearson Education Limited.

Schwandt, T. A. (2001). Dictionary of qualitative inquiry (2nd ed.). Thousand Oaks, CA: Sage.

Scott, P., Mortimer, E., \& Ametller, J. (2011). Pedagogical link-making: A fundamental aspect of teaching and learning scientific conceptual knowledge. Studies in Science Education, 47(1), 3-36. https://doi.org/10.1080/03057267.2011.549619

Seidel, T., \& Shavelson, R. J. (2007). Teaching effectiveness research in the past decade: The role of theory and research design in disentangling meta-analysis results. Review of educational research, 77(4), 454-499. https:/ / doi.org/10.3102/0034654307310317

Shuell, J. P. (1988). The role of the student in learning from instruction. Contemporary Educational Psychology, 13(3), 276-295. https:/ / doi.org/10.1016/0361-476X(88)90027-6

Signh, K. (2007). Quantitative social research methods. Thousand Oaks, CA: Sage Publications.

Sogunro, O. A. (2004). Efficacy of role-playing pedagogy in training leaders: Some reflections. Journal of Management Development, 23(4), 355-371. https:/ / doi.org/10.1108/02621710410529802

Umalusi. (2014). Report on the quality assurance of examinations and assessments of the National Senior Certificate (NSC) 2010. Retrieved from http:/ / www.umalusi.org.za/list.php?type=Quality\%20Assurance \%20Reports\&year=2014

Westrup, U., \& Planander, A. (2013). Role-play as a pedagogical method to prepare students for practice: The students' voice. Ogre utbildning, 3(3), 199-210.

Wicks, J., \& Raborife, M. (2017, January 4). Progressed learners' could affect matric pass rate. News24. Retrieved from https://www.news24.com/SouthAfrica/News/progressed-learners-could-have-impact-on-matricpass-rate-20170104

Winfrey, O. (2006, March). Aha! moments. O Magazine. Retrieved from http://www.oprah.com/omagazine/ahamoments

Woolfolk, A. E., Winne, P. H., Perry, N. E., \& Shapka, J. (2010). Educational Psychology (4th ed.). Toronto: Pearson Canada.

Yin, R. K. (2003). Case study research: Design and methods (3rd ed.). Thousand Oaks, CA: Sage.

Zenda, R. (2017). Essential teaching methods to enhance learner academic achievement in physical sciences in rural secondary schools: A South African case study. Information and Learning Science, 118(3), 170-184. https:/ / doi.org/10.1108/ILS-03-2017-0014 


\section{APPENDIX A}

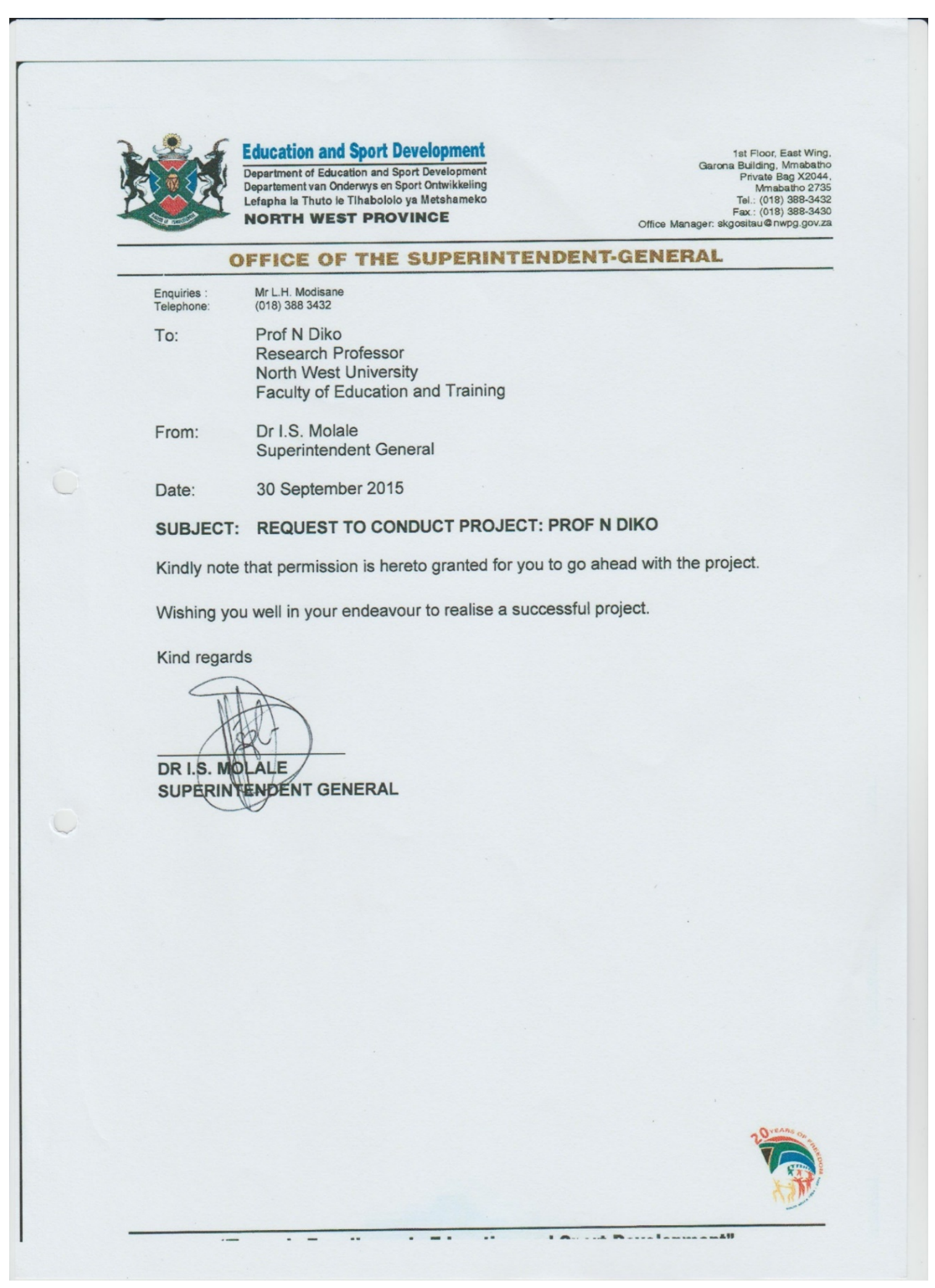




\section{APPENDIX B}

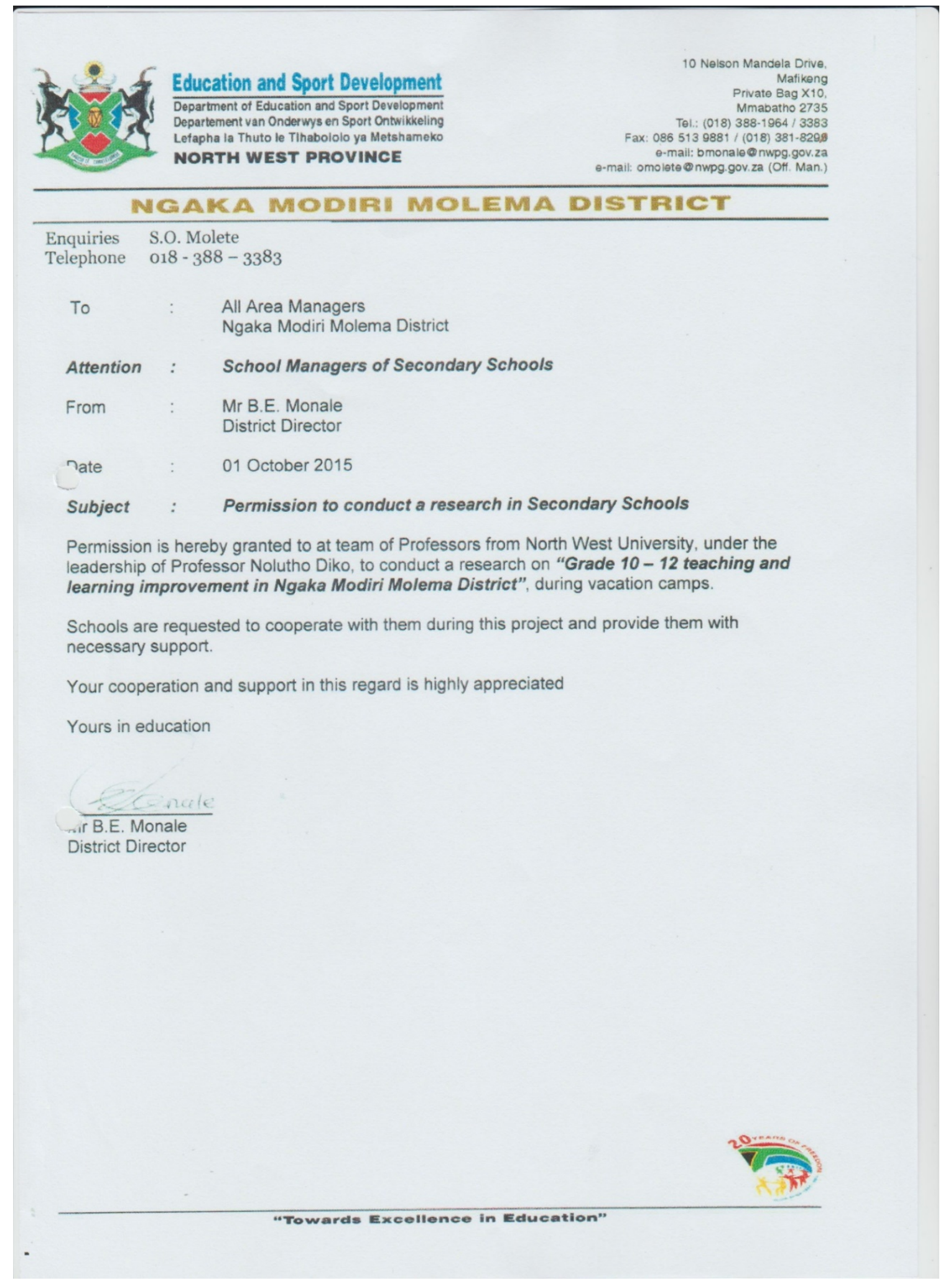

http://www.ejmste.com 